\title{
Evaluation of a Voluntary Control Program for the Detection of Bovine Leukemia Virus Antibodies Based on Agar Gel Immunodiffusion Test in Dairy Farms in Costa Rica
}

\author{
Gaby Dolz*, Francine Huijsen, Carlos Jiménez, Luis L. Rodríguez \\ Escuela de Medicina Veterinaria, Universidad Nacional, Heredia, Costa Rica \\ Email: " gaby.dolz.wiedner@una.cr
}

Received 30 October 2015; accepted 6 December 2015; published 11 December 2015

Copyright (C) 2015 by authors and Scientific Research Publishing Inc.

This work is licensed under the Creative Commons Attribution International License (CC BY).

http://creativecommons.org/licenses/by/4.0/

(c) () Open Access

\begin{abstract}
Cattle from 20 dairy farms were serologically tested over a five-year period using agar gel immunodiffusion test (AGIDT) as part of a voluntary Bovine Leukemia Virus (BLV) control program. After five years of removing infected animals from the herds based on BLV-AGIDT serological status, blood samples from 332 cattle in these farms were collected and analyzed side by side by AGIDT and enzyme-linked immunosorbent assay (ELISA) to detect antibodies against BLV. AGIDT detected $29.2 \%(97)$ and $16.0 \%$ (53) of the animals as positive and weak positive respectively, whereas ELISA detected $58.2 \%(193)$ cattle as positive. The prevalence of BLV-antibodies determined with AGIDT in the dairy farms oscillated between $0 \%$ and $86 \%$, whereas prevalence determined by ELISA ranged between $28 \%$ and $100 \%$ in the same farms. Although both techniques showed similarly results in farms with high BLV-prevalence, ELISA detected a larger proportion of BLVpositive, especially in farms with low or no BLV-prevalence based on AGIDT, leading to wrong assumptions in terms of farm level control efforts. Our results strongly suggest that AGIDT alone is inadequate to implement BLV control programs and ELISA is a more adequate test for BLV surveillance and control programs.
\end{abstract}

\section{Keywords}

BLV, Serological Testing, Control Programs

\footnotetext{
${ }^{*}$ Corresponding author.
}

How to cite this paper: Dolz, G., Huijsen, F., Jiménez, C. and Rodríguez, L.L. (2015) valuation of a Voluntary Control Program for the Detection of Bovine Leukemia Virus Antibodies Based on Agar Gel Immunodiffusion Test in Dairy Farms in Costa Rica. Open Journal of Veterinary Medicine, 5, 229-233. http://dx.doi.org/10.4236/ojvm.2015.512031 


\section{Introduction}

Bovine leukemia virus (BLV), an exogenous retrovirus, is the infectious agent responsible for causing enzootic bovine leucosis (EBL), the most frequent neoplasm of lymphatic tissue in cattle [1]. This agent can induce lymphocyte transformation and eventually, development of lymphosarcomatous tumors after long incubation periods. However, BLV replicates in B-lymphocytes and cattle become infected by exposure to virus infected lymphocytes. Cattle with antibodies against BLV are persistently infected and represent a source of infection for other animals [2].

Control and eradication programs are mainly based on detection of seropositive animals followed by elimination, segregation or implementation of corrective management [3]. The agar gel immunodiffusion test (AGIDT) has been the test of choice for routine diagnosis and is still prescribed for international trade [4] [5]. Although AGIDT is a simple and reliable procedure, it has a relatively low sensitivity, which might favor the occurrence of low-titer BLV infections in clinically normal herds [5]-[7]. This is of remarkable importance in herds which had been tested repeatedly for some time with AGIDT [8] [9]. Previous results showed that control based solely on low sensitivity precipitation assays might complicate the epidemiology of BLV by selecting animals which, although infected, do not produce detectable antibodies in AGIDT. For its high sensitivity, the enzyme-linked immunosorbent assay (ELISA) is considered to be the most adequate test for future survey and control programs [9]-[13]. Several immunoenzymatic assays have been developed, even molecular assays, and compared to AGIDT [7] [10] [14]-[16]. This study was designed to compare and evaluate AGIDT and ELISA for the detection of antibodies to BLV in twenty dairy farms in Costa Rica that were tested repeatedly during five years with AGIDT as part of a voluntary EBL control program.

\section{Material and Methods}

\subsection{Bovine Sera}

332 bovine sera from dairy cattle were collected from 20 farms located in the outskirts of the Poás volcano in the Vara Blanca region in Heredia, Costa Rica.

\subsection{Agar Gel Inmunodiffusion Test (AGIDT)}

Leukassay $\mathrm{B}^{\mathrm{R}}$ (Pittman Moore Inc., Mundelein, IL, USA) was performed as recommended by the manufacturers. A layer, $3.5 \mathrm{~mm}$ thick, of $0.8 \%$ type IV agarose, dissolved in $0.05 \mathrm{M}$ Tris- $\mathrm{HCl}, 8.5 \% \mathrm{NaCl}$, $\mathrm{pH} 7.2$, was poured into bacteriological polystyrene plates. The pattern of six peripheral wells filled with positive control sera and bovine sera, and one central well filled with antigen was used.

\subsection{Enzyme-Linked Immunosorbent Assay (ELISA)}

The ELISA was performed using the leukosis indirect ELISA kit kindly donated by the Joint FAO/IAEA Programme. This ELISA was conducted according to the test protocol submitted with some modifications. BLV-antigen was diluted 1:1000 with 0.05 M carbonate buffer, pH 9.6. Microtiterplates (Polysorp, Fa. Nunc) were coated with BLV-antigen $\left(100 \mu \mathrm{l}\right.$ per well) and incubated $16 \mathrm{~h}$ at $4{ }^{\circ} \mathrm{C}$. The plates were washed three times with washing buffer (0.02 M PBS, 0.05\% Tween-20). Bovine control and test sera diluted 1:50 in PBS (containing $1 \mathrm{M}$ NaCI, $0.05 \%$ Tween-20) were added to the wells $\left(100 \mu \mathrm{l}\right.$ per well) and incubated $1 \mathrm{~h}$ at $37^{\circ} \mathrm{C}$. Positive, weak positive and negative control sera were added in quadruplicate, and test sera in duplicate to the plates.

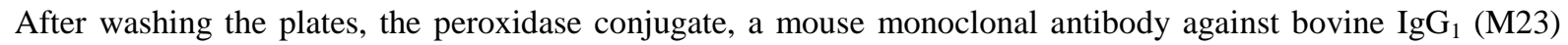
was diluted 1:20.000 in PBS, 0.05\% Tween-20, and added to each well, and the plate was incubated for $1 \mathrm{~h}$ at $37^{\circ} \mathrm{C}$. After washing, $100 \mu \mathrm{l}$ peroxidase substrate $(0.05 \mathrm{M}$ phosphate citrate buffer, $\mathrm{pH} 5.0$, containing 0.416 $\mathrm{mM}$ TMB, $1.75 \mathrm{mM} \mathrm{H}_{2} \mathrm{O}_{2}$ ) was added to each well. After 15 minutes substrate chromogen incubation $100 \mu$ of stopping solution ( $2 \mathrm{M} \mathrm{H}_{2} \mathrm{SO}_{4}$ ) was added to each well. The optical density (OD) was measured at $450 \mathrm{~nm}$ in a Titertek Multiscan ${ }^{\mathrm{R}}$ Plus MKII (Flow Laboratories). The optical densities were expressed as positive percentage (PP) with respect to the OD of the mean of the positive controls of each plate (mean OD of the positive control sera $=100 \%$ PP). All tested sera that showed PP values of $25 \%$ and higher with respect of the positive control of the plate were considered positive in this investigation. 


\subsection{Statistical Analysis}

Sensitivity, specificity, predictive positive and predictive negative values for the AGIDT, compared to the ELISA, were calculated with Epinfo Software.

\section{Results}

From 332 sera analyzed, 97 (29.2\%) showed positive, 53 (16.0\%) showed weak positive reactions and 182 (54.8\%) reacted negative in AGIDT. In contrast, 193 (58.2\%) reacted positive and 139 (41.9\%) negative in ELISA (Table 1). The relative sensitivity and specificity of the AGIDT with respect to the ELISA for the 332 sera were $73.0 \%$ and $96.0 \%$, respectively; predictive positive and negative values were $74.6 \%$ and $95.6 \%$, respectively. From 97 sera with positive reactions in AGIDT, 96 (98.9\%) were confirmed positive and one (1.1\%) reacted negative in ELISA. From 53 sera with weak positive reactions in AGIDT, 48 (90.5\%) were confirmed positive and five (9.5\%) reacted negative in ELISA. From 182 sera that reacted negative in AGIDT, 49 (26.9\%) reacted positive and 133 (73.1\%) reacted negative in ELISA (Figure 1).

The prevalence of BLV-antibodies determined with AGIDT in 20 dairy farms oscillated between $0 \%$ and $86 \%$, however, the ELISA determined prevalence ranged from 28\% - 100\% (Figure 1). Although both techniques showed similar results in farms with high BLV-prevalence, ELISA detected a larger proportion of BLV-positive cows in farms with low prevalence of BLV-antibodies in AGIDT (Figure 1).

\section{Discussion}

The results of AGIDT with 332 sera of dairy cattle collected in the Poás region of Costa Rica (45.2\% positivity) were in accordance with those from other authors [9] [17]-[19]. However, the proportion of positive animals increased to 58.1\% when ELISA was used. The determined relative sensitivity and specificity of AGIDT was also in accordance with other reports that conferred AGIDT a lower sensitivity compared to ELISA [4] [7] [9]-[13].

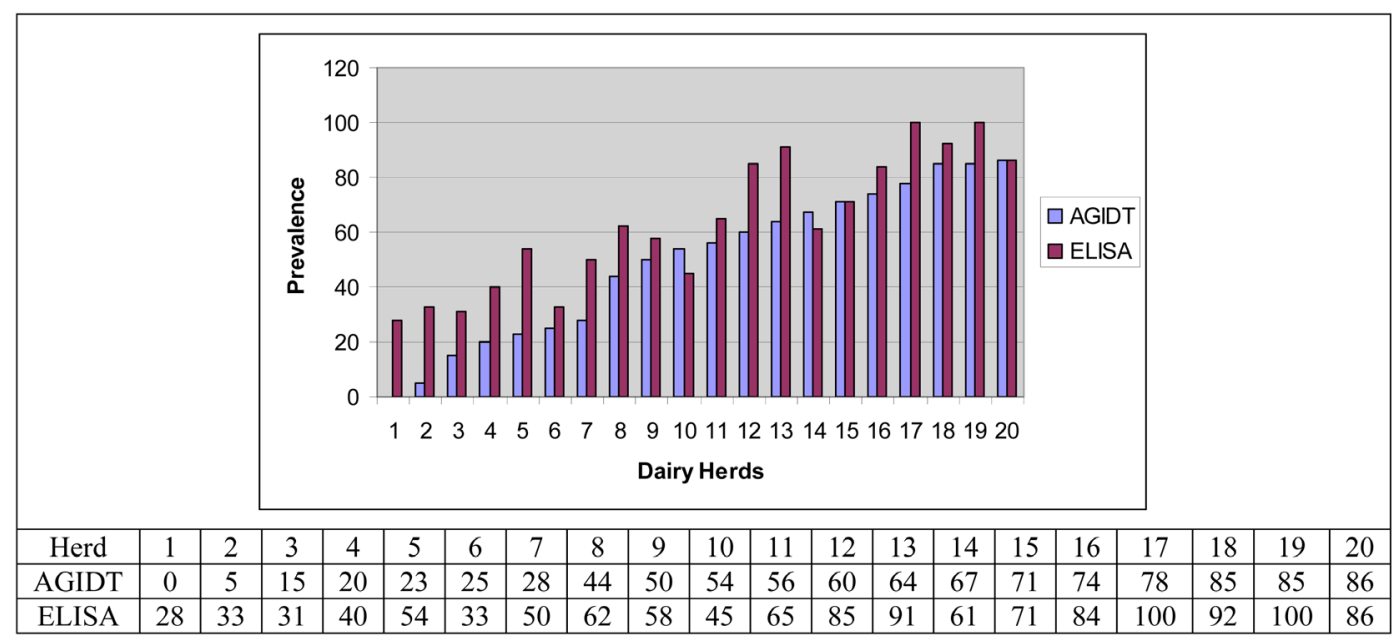

Figure 1. Prevalence of BLV-infection in twenty dairy herds of Costa Rica detected by AGIDT and ELISA.

Table 1. Detection of antibodies against BLV in 322 bovine sera, comparison AGIDT and ELISA.

\begin{tabular}{|c|c|c|c|c|}
\hline \multirow{6}{*}{ AGIDT } & \multicolumn{4}{|c|}{ ELISA } \\
\hline & & + & - & $\Sigma$ \\
\hline & + & 96 (28.9\%) & $1(0.3 \%)$ & 97 (29.2\%) \\
\hline & \pm & 48 (14.5\%) & $5(1.5 \%)$ & 53 (16\%) \\
\hline & - & 49 (14.8\%) & 133 (40.0\%) & $182(54.8 \%)$ \\
\hline & $\Sigma$ & 193 (58.2\%) & 139 (41.8\%) & 332 (100\%) \\
\hline
\end{tabular}

$+=$ positive reactions; $\pm=$ weak positive reactions; $-=$ negative reactions; $\Sigma=$ total. 
The use of the AGIDT failed generally in dairy farms with low BLV-prevalence. A possible explanation is that the antibody content in the sera of the animals tested was under the detection limit of the assay. The same behavior was described by Manz and Bauer [8] and Dolz and Moreno [9]. They showed a failure of the AGIDT compared to ELISA in herds controlled during a long time with AGIDT due to the fact that many AGIDT negative animals were low titer reactors in ELISA. Although non-specific reactions are relatively common in ELISA, and difficult to distinguish from specific ones, the ELISA used in this study was determined previously as high specific (100\%), using Western Blotting as confirmatory test [9].

In countries with high prevalence of BLV-infection such as Costa Rica, where the management of dairy herds and probably the presence of bloodsucking vectors promote the spreading of the virus, tests with relatively low sensitivity are not adequate for control programs, since they may favor the maintenance of BLV in clinically normal cattle [4] [7] [9]-[13]. Our results with sera from the 20 dairy farms strongly suggest that control based solely on low sensitivity precipitation assay might complicate the epidemiology by selecting animals, which although infected, do not produce detectable antibodies in AGIDT. Based on the fact the ELISA is more sensitive, allows expedited testing of large number of samples and the test outcome is an objective numerical reading, we consider ELISA as the most adequate test for survey and control programs in Costa Rica.

\section{Acknowledgements}

The authors wish to thank Enrique Pérez and Ronald Dwinger for their help and support. This investigation was supported by FAO-International Atomic Energy Agency (IAEA), Austria and Vicerrectoría de Investigación, Universidad Nacional, Costa Rica.

\section{References}

[1] Burny, A., Bex, F., Chartrenne, H., Cleuter, Y., Dekegel, D., Ghysdael, J., Kettmann, R., Leclerc, M., Mammerickx, M. and Portetelle, D. (1978) Bovine Leukemia Virus Involvement in Enzootic Bovine Leucosis. Advances in Cancer Research, 28, 251-311. http://dx.doi.org/10.1016/S0065-230X(08)60649-1

[2] Dimmock, C.K., Chung, Y.S. and Mackenzie, A.R. (1991) Factors Affecting the Natural Transmission of Bovine Leukaemia Virus Infection in Queensland Dairy Herds. Australian Veterinary Journal, 68, 230-233. http://dx.doi.org/10.1111/j.1751-0813.1991.tb03213.x

[3] Johnson, R. and Kaneene, J. (1992) Bovine Leukaemia Virus and Enzootic Bovine Leucosis. Veterinary Bulletin, 62, 287-305.

[4] Trono, K.G., Pérez-Filgueira, D.M., Duffy, S., Borca, M.V. and Carrillo, C. (2001) Seroprevalence of Bovine Leukemia Virus in Dairy Cattle in Argentina: Comparison of Sensitivity and Specificity of Different Detection Methods. Veterinary Microbiology, 83, 235-248. http://dx.doi.org/10.1016/S0378-1135(01)00420-5

[5] OIE (World Organization for Animal Health) (2012) Enzootic Bovine Leucosis. http://www.oie.int/fileadmin/Home/fr/Health_standards/tahm/2.04.11_EBL.pdf

[6] Choi, K.Y., Liu, R.B. and Buehring, G.C. (2002) Relative Sensitivity and Specificity of Agar Gel Immunodiffusion, Enzyme Immunosorbent Assay, and Immunoblotting for Detection of Anti-Bovine Leukemia Virus Antibodies in Cattle. Journal of Virological Methods, 104, 33-39. http://dx.doi.org/10.1016/S0166-0934(02)00040-X

[7] Gutiérrez, G., Alvarez, I., Fondevila, N., Politzki, R., Lomónaco, M., Rodríguez, S., Dus Santos, M.J. and Trono, K. (2009) Detection of Bovine Leukemia Virus Specific Antibodies Using Recombinant p24-ELISA. Veterinary Microbiology, 137, 224-34. http://dx.doi.org/10.1016/j.vetmic.2009.01.022

[8] Manz, D. and Bauer, T. (1985) Ergebnisse serologischer Untersuchungen auf enzootische bovine Leukosis in Abhängigkeit vom Stand der staatlichen Bekämpfungsverfahren. Tierärztliche Umschau, 40, 155-160.

[9] Dolz, G. and Moreno, E. (1999) Comparison of Agar Gel Immunodiff usion Test, Enzyme-Linked Immunosorbent Assay and Western Blotting for the Detection of BLV Antibodies. Journal Veterinary Medicine, Series B, 46, 551-558. http://dx.doi.org/10.1111/j.1439-0450.1999.tb01248.x

[10] Reichel, M.P., Tham, K.M., Barnes, S. and Kittelberger, R. (1998) Evaluation of Alternative Methods for the Detection of Bovine Leukaemia Virus in Cattle. New Zealand Veterinary Journal, 46, 140-146. http://dx.doi.org/10.1080/00480169.1998.36078

[11] Simard, C., Richardson, S., Dixon, P., Belanger, C. and Maxwell, P. (2000) Enzyme-Linked Immunosorbent Assay for the Diagnosis of Bovine Leucosis: Comparison with the Agar Gel Immunodiffusion Test Approved by the Canadian Food Inspection Agency. Canadian Journal of Veterinary Research, 64, 101-106.

[12] Felmer, R., Zuñiga, J. and Recabal, M. (2006) Estudio comparativo de un PCR anidado, ELISA y AGID en la 
detección del virus de la leucosis bovina en muestras de suero, sangre y leche. Archivos de Medicina Veterinaria, 38, 137-141. http://dx.doi.org/10.4067/s0301-732x2006000200007

[13] Nava, Z., Obando, C., Bracamonte, M., Sousa, A. and Hidalgo, M. (2012) Evaluación de la eficacia de la prueba de inmunodifusión en gel agar para la detección de anticuerpos contra el virus de la leucosis enzootica bovina. Revista de la Facultad de Ciencias Veterinarias, 53, 21-27.

[14] Monti G.E., Frankena, K., Engel, B., Buist, W., Tarabla, H.D. and de Jong, M.D. (2005) Evaluation of a New Antibody-Based Enzyme-Linked Immunosorbent Assay for the Detection of Bovine Leukemia Virus Infection in Dairy Cattle. Journal of Veterinary Diagnostic Investigations, 17, 451-417. http://dx.doi.org/10.1177/104063870501700507

[15] de Castro, C.C., Nunes, C.F., Finger, P.F., Siedler, B.F., Dummer, L., de Lima, M., Leite, F.P., Fischer, G., Vargas, G.D. and Hübner, S.D.O. (2013) Peroxidase-Linked Assay for Detection of Antibodies against Bovine Leukosis Virus. Journal of Immunoassay and Immunochemistry, 34, 376-383. http://dx.doi.org/10.1080/15321819.2012.747442

[16] Troiano, L.D., Thomaz-Soccol, V., Agottani, J.V., Brodzinski, J., Penha, T.R. and Ozaki, S.C. (2013) Production, Characterization, and Use of Monoclonal Antibodies against gp51 Protein to Diagnose Bovine Leukemia Virus Infection. BioResearch Open Access, 2, 55-60. http://dx.doi.org/10.1089/biores.2012.0295

[17] Rodríguez, L., Esquivel, R. and Alvarado, J. (1980) Bovine Viral Leukaemia in Dairy Herds of the Central Valley of Costa Rica. Ciencias Veterinarias, 2, 183-194.

[18] Jiménez, C., Bonilla, J., Dolz, G., Rodríguez, L., Herrero, L., Bolaños, E., Cortez, R. and Moreno, E. (1995) Bovine Leukemia-Virus Infection in Costa Rica. Journal of Veterinary Medicine, Series B, 42, 385-390. http://dx.doi.org/10.1111/j.1439-0450.1995.tb00726.x

[19] Beita, G. (2008) Epidemiología de la leucosis viral bovina en hatos lecheros especializados de Costa Rica. Bachelor Thesis, Universidad Nacional de Costa Rica, Heredia. 